\title{
PERANAN VITAMIN B12 DALAM PENGENCER SUSU SKIM KUNING TELUR TERHADAP MOTILITAS DAN VIABILITAS SPERMATOZOA DOMBA SAPUDIPOST THAWING
}

\section{THE ROLE OF VITAMIN B12 IN THE EGG YOLK SKIM MILK EXTENDER TOWARDSTHE MOTILITY AND VIABILITY OF POST THAWING SAPUDI SHEEP SPERMATOZOA}

\author{
Mirza Asafaizh Arini ${ }^{1}{ }^{*}{ }^{*}$ Tri Wahyu Suprayogi ${ }^{2}$, Sunaryo Hadi Warsito ${ }^{3)}$, \\ Trilas Sardjito $^{4)}$, Suherni Susilowati ${ }^{5)}$, Indah Norma Triana ${ }^{6)}$ \\ ${ }^{1)}$ Student, ${ }^{2,4,5,6}$ Departement of Veterinary Reproduction, ${ }^{3)}$ Department of Animal Husbandry \\ Faculty of Veterinary Medicine, Universitas Airlangga \\ *Corresponding author: email: twsuprayogi@gmail.com; mirzaasafaizh@gmail.com
}

\begin{abstract}
The purpose of this study was to prove that the addition of Vitamin B12 in egg yolk skim milk extender can maintain the motility and viability of post thawing Sapudi sheep spermatozoa. This study used sample of Sapudi sheep fresh semen that was collected with artificial vagina, and divided into 3 different treatments. The control treatment or P0, Sapudi sheep semen was diluted in the egg yolk skim milk extender + vitamin C 0,02 mg / ml, treatment group (P1 and P2), Sapudi sheep semen was diluted in the egg yolk skim milk extender+ vitamin B12 $5 \mu \mathrm{g} / \mathrm{ml}$ and grouped in P1, Sapudi sheep semen was diluted in the egg yolk skim milk extender + Vitamin C $0.02 \mathrm{mg} / \mathrm{ml}+$ Vitamin B12 $5 \mu \mathrm{g} / \mathrm{ml}$ and grouped in P2. The data analysis was use One Way Analysis of Variant (ANOVA), then to identify the real difference among the treatments continued with Duncan distance test. The result of data analysis showed that P2 treatment was significantly different $(\mathrm{p}<0.05)$ with $\mathrm{P} 1$ treatment and P0 treatment or control. While P1 treatment was not significantly different $(\mathrm{p}>0,05)$ with P0 treatment or control. The result showed that the addition of vitamin C $0.02 \mathrm{mg} / \mathrm{ml}$ with vitamin B12 $5 \mu \mathrm{g} / \mathrm{ml}$ combination in egg yolk skim milk extender was the best addition to maintain the motility and viability of the post thawing Sapudi sheep spermatozoa.
\end{abstract}

Keyword :Sapudi sheep spermatozoa, egg yolk skim milk extender, vitamin B12, motility, viability.

\section{Pendahuluan}

Domba merupakan salah satu jenis ternak yang banyak dipelihara oleh masya-rakat Indonesia. Secara umum, domba lokal di Jawa Timur didominasi oleh domba Sapudi. Domba Sapudi sangat cocok untuk diternakkan dan dipelihara karena domba ini tahan beradaptasi pada kondisi kering dan panas dimana penyimpanan cadangan tubuh dilakukan dibagian ekornya yang berlemak (Tiesnamurti dan Santiananda 2006).

Untuk menunjang keberhasilan usaha peternakan maka perlu meningkatkan produktivitas reproduksi ternak. Upaya peningkatan produktivitas reproduksi dapat dicapai dengan teknologi inseminasi buatan (IB) yang bertujuan untuk memanfaatkan potensi seekor pejantan unggul secara
maksimal(Pamungkas, 2009). Inseminasi buatan pada ternak domba di Indonesia saat ini belum banyak dilaporkan tingkat keberhasilannya pada kondisi lapangan namun di prediksi tingkat kebuntingannya masih di bawah 30\% (Inounu, 2014).

Keberhasilan IB di lapangan tergantung kualitas semen yang digunakan. Semen yang umum digunakan pada teknologi IB adalah semen beku. Keuntungan menggunakan semen beku adalah untuk memperluas jangkauan distribusi semen dan memperpanjang umur penyimpanan semen tersebut (Hardijanto dkk., 2010).

Rendahnya angka fertilitas pada domba disebabkan karena spermatozoa domba lebih sensitif terhadap cold shock dibandingkan spesies lain (Muino-Blanco et al., 
2008).Hardijanto dkk. (2010) mengatakan bahwa kandungan kolesterol pada membran plasma spermatozoa domba dan kambing lebih sedikit dibanding sapi, semakin sedikit kandungan kolesterol pada membran sel akan menyebabkan spermatozoa mudah mengalami kerusakan karena fungsi kolesterol untuk mengatur fluiditas dan permeabilitas membran sel.

Proses pembekuan semen sangat rentan merusak struktur membran plasma spermatozoa itu sendiri. Menurut Gazali dan Surya (2002) kerusakan yang terjadi salah satunya adalah peroksidasi lipid. Peroksidasi lipid terjadi karena adanya radikal bebas yang sangat reaktif bereaksi dengan asam lemak tak jenuh penyusun utama fosfolipid membran spermatozoa. Dengan sedikitnya jumlah kolesterol penyusun lipid membran pada spermatozoa domba, maka akan semakin mempermudah terjadinya kerusakan saat proses pembekuan semen domba yang mengakibatkan rendahnya motilitas dan viabilitas spermatozoa.

Kerusakan membran plasma semen akibat radikal bebas dapat dicegah dengan pemberian antioksidan dalam pengencer. Vitamin B12 adalah salah satu vitamin yang larut dalam air. Vitamin ini berfungsi sebagai koenzim dalam sintesis metionin (Juanchi et al., 2000). Sintesis metionin dapat menghasilkan metilasi organ - organ fungsional seperti DNA, RNA, neurotransmitter, lipid, dan asam amino penyusun sel serta dapat mengurangi stress oksidatif yang dipicu oleh proses pembekuan dan meningkatkan kualitas semen (Banihani, 2017).

Selama ini pemberian antioksidan dalam pengencer semen menggunakan vi-tamin $\mathrm{C}$. Vitamin $\mathrm{C}$ merupakan antioksidan yang dapat menangkal radikal bebas. Setyaningsih (2012) mengatakan bahwa meningkatkan pemberian dosis vitamin $\mathrm{C}$ dalam pengencer akan menurunkan kualitas semen. Karena sifat vitamin $\mathrm{C}$ yang asam apabila ditambahkan dalam jumlah berlebih akan mempengaruhi $\mathrm{pH}$ pengencer menjadi asam, spermatozoa akan mati apabila kondisi lingkungan sekitarnya menjadi asam (Rizal dan Herdis, 2010).

Berdasarkan latar belakang di atas maka perlu dilakukan penelitian untuk mengetahui peranan penggantian dan penambahan vitamin B12 dalam pengencer susu skim kuning telur dibandingkan peranan vitamin $\mathrm{C}$ dalam pengencer susu skim kuning telur terhadap persentase motilitas dan viabilitas spermatozoa domba Sapudi post thawing.

\section{Metode Penelitian}

Sampel yang digunakan dalam pene-litian ini adalah semen domba yang berasal dari pejantan domba Sapudi berumur 1,5 - 2 tahun. Penelitian ini dilaksanakan di Taman Ternak Pendidikan Fakultas Kedokteran Hewan Universitas Airlangga, desa Tanjung kecamatan Kedamean kabupaten Gresik pada bulan Maret - Mei 2018.

Semen dikoleksi menggunakan vagina buatan dengan frekuensi penampungan satu kali seminggu/pejantan. Penelitian ini menggunakan satu kali ejakulat dan dibagi menjadi tiga perlakuan dan dilakukan enam kali ulangan. Segera setelah penampungan, semen dievaluasi secara makroskopis meliputi volume, warna, bau, konsistensi dan $\mathrm{pH}$ serta secara mikroskopis meliputi gerakan massa, gerakan individu, konsentrasi spermatozoa, jumlah spermatozoa yang hidup atau mati dan abnormal. Hanya semen yang mempunyai gerakan massa $\geq++$ dan gerakan individu dan daya hidup spermatozoa $\geq 70 \%$, abnormalitas $<15 \%$ dan konsentrasi $>2000 \mathrm{juta} / \mathrm{ml}$ digunakan dalam penelitian ini

Bahan pengencer yang digunakan adalah susu skim kuning telur yang dibuat sesuai prosedur yang diterapkan oleh Fakul-tas Kedokteran Hewan Universitas Airlang-ga Surabaya. Sebanyak 10\% skim milk (Tropicana Slim) dilarutkan dengan aquadest, dipanaskan sampai suhu $90-92^{\circ} \mathrm{C}$ selama 10 menit. Setelah dingin disaring dan ditambahkan pada kuning telur $5 \mathrm{ml}$ hingga volume akhir larutan $100 \mathrm{ml}$. Selanjutnya ditambahkan antibiotik (Penicillin 1000 $\mathrm{IU} / \mathrm{ml}$ dan Streptomycin $1 \mathrm{mg} / \mathrm{ml}$ ) dan fruktosa $0,5 \%$ dan dinamakan larutan A. Pengencer semen beku adalah larutan B yang terdiri dari susu skim kuning telur yang telah diberi antibiotik dan fruktosa ditambahkan $10 \%$ gliserol dan $2 \%$ glukosa.

Semen yang memenuhi persyaratan di-bagi dalam 3 kelompok perlakuan pengen-cer susu skim kuning telur. Semen yang diencerkan pada pengencer susu skim telur dengan penambahan vitamin $\mathrm{C} 0,02 \mathrm{mg} / \mathrm{ml}$ (P0); pengencer susu skim kuning telur 
dengan penambahan vitamin B12 $5 \mu \mathrm{g} / \mathrm{ml}$ (P1); pengencer susu skim kuning telur dengan penambahan kombinasi Vitamin $\mathrm{C}$

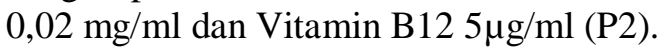

Semen yang telah diencerkan didingin-kan pada dalam cool top suhu $3-5^{\circ} \mathrm{C}$ selama 1 jam. Setelah itu dilakukan proses gliserolisasi dengan mencampur diluter B dengan diluter A yang dilakukan secara bertahap dan perlahan-lahan melalui dinding tabung dalam suhu $5^{\circ} \mathrm{C}$ selama 1 jam kemudian diequilibrasi pada suhu $5^{\circ} \mathrm{C}$ selama 1 jam. Proses selanjutnya adalah pemeriksaan before freezing dengan melihat motilitas dan viabilitas spermatozoa di bawah mikroskop dengan pembesaran berturut - turut 100 kali dan 400 kali. Spermatozoa dinyatakan layak dengan persentase motilitas dan viabilitas $\geq 55 \%$. Setelah itu dikemas dalam ministraw 0,25 ml. Kemudian melakukan proses pre freezing dengan cara meletakkan ministraw 1-2 $\mathrm{cm}$ di atas permukaan $\mathrm{N}_{2}$ cair selama 9 menit pada suhu $-140^{\circ} \mathrm{C}$, kemudian melakukan proses freezing dengan menenggelamkan ministraw ke dalam $\mathrm{N}_{2}$ cair pada suhu $-196^{\circ} \mathrm{C}$ (Susilowati dkk., 2010).Thawing semen beku domba menggunakan air hangat dengan suhu $\pm 37^{\circ} \mathrm{C}$ selama 15 detik. Setelah itu dilakukan pemeriksaan kualitas semen meliputi persentase motilitas dan viabilitas. Motilitas spermatozoa diperiksa de-ngan cara menempatkan satu tetes semen yang telah diencerkan pada gelas objek yang hangat yaitu bersuhu $37^{\circ} \mathrm{Cditutup}$ dengan gelas penutup dan memeriksannya dibawah mikroskop dengan pembesaran 100 kali. Penilaian motilitas ini berdasarkan pada arah gerak spermatozoa dinyatakan dalam persen (\%)dan kecepatan gerak dari spermatozoadinyatakan dengan angka.

Jumlah spermatozoa yang hidup di-hitung dengan meneteskan setetes kecil se-men yang telah diencerkan pada gelas objek yang bersih dan mencampurnya dengan setetes besar zat warna eosin negrosin sampai homogen. Pembuatan preparat ulas dengan caraslide dan memfiksasi di atas api. Pengamatan spermatozoa yang hidup dan mati dilakukan di bawah mikroskop dengan penghitungan minimal 100 spermatozoa dengan pembesaran 400 kali

\section{Analisis Data}

Data yang diperoleh disusun dalam sa-tu tabel, selanjutnya perbedaan motilitas dan viabilitas dianalisis dengan menggu-nakan Analysis of Variance (ANOVA) One Way, kemudian untuk mengetahui perbeda-an yang nyata antar perlakuan dilanjutkan dengan uji jarak Duncan dengan program SPSS 22 for windows (Kusriningrum, 2008).

\section{Hasil dan Pembahasan}

\section{Kualitas Semen Segar Domba Sapudi}

Pemeriksan makroskopis dan mikros-kopis semen segar domba Sapudi dilakukan untuk untuk mengetahui kualitas dan kuan-titas semen domba yang akan diproses men-jadi semen beku. Hasil pemeriksaan semen segar domba Sapudi dapat dilihat pada tabel 1 dan 2.

Berdasarkan tabel 1 dan 2, semen segar domba Sapudi memiliki kualitas yang baik, sehingga layak diproses lebih lanjutdalam bentuk semen semen beku.

\section{Pemeriksaan Persentase Motilitas SpermatozoaPost Thawing}

Hasil pemeriksaan persentase motilitas spermatozoa domba Sapudi post-thawing setelah diberi perlakuan. Pada penelitian inimeninjau motilitas spermatozoa berdasar-kan arah dan kecepatan gerak spermatozoa.Hasil pemeriksaan post thawing motility spermatozoa dapat dilihat dalam tabel 3 .

Tabel 1. Hasil Pemeriksaan Makroskopis Semen Segar Domba Sapudi.

\begin{tabular}{ll}
\hline Parameter & Ukuran \\
\hline Volume $(\mathrm{ml})$ & $1,2 \pm 0,160$ \\
Warna & Putih Krem \\
Bau & Khas \\
$\mathrm{pH}$ & $6-7$ \\
Konsistensi & Kental \\
\hline
\end{tabular}

Keterangan : bau semen khas semen Domba Sapudi (prengus) 
Tabel 2. Hasil Pemeriksaan Mikroskopis Semen Segar Domba Sapudi.

\begin{tabular}{ll}
\hline Parameter & Ukuran \\
\hline Konsentrasi (Juta/ml) & $5.533 \pm 890,2$ \\
Gerakan Individu (\%) & $87,5 \pm 2,88$ \\
Gerakan Massa & +++ \\
Kecepatan & $3,5 \pm 0,58$ \\
Viabilitas Spermatozoa (\%) & $93,3 \pm 2,50$ \\
Abnormalitas (\%) & $6,98 \pm 0,83$ \\
\hline Keferat
\end{tabular}

Keterangan : $+++\quad=$ sangat baik. Jika terlihat gelombang - gelombang besar.tebal, banyak,dan aktif bergerak.

Peranan vitamin $\mathrm{C}$ dapat mengikat ra-dikal oksigen yang terdapat dalam sel se-hingga dapat mencegah terbentuknya pe-roksidasi lipid yang menghambat motilitas spermatozoa. Vitamin Cdapat bereaksi langsung dengan radikal bebas yang reaktif larut dalam air. Reaksi pengikatan radikal bebas oleh asam askorbat berupa :

$\mathrm{R}^{\circ}+\mathrm{AH} \longrightarrow \mathrm{RH}+\mathrm{A}^{\circ}$. Asam askorbat bereaksi dengan radikal bebas dengan mengikat elektron tak berpasangan dari radikal tersebut dan menghasilkan antioksidan tereduksi $\left(\mathrm{A}^{\circ}\right)$, antioksidan tereduksi ini tidak memiliki cukup energi untuk menimbulkan reaksi radikal berbahaya (Nimse and Dilipkumar, 2015).

Produksi ROS yang berlebihan akan memulai reaksi rantai oksidasi yang merusak protein, lipid dan DNA spermatozoa (Asadpour et al., 2012). Vitamin B12 merupakan antioksidan yang berfungsi sebagai koenzim dalam proses sintesis metionin. Enzim ini diperlukan untuk men-sintesis metionin dari homosistein untuk melengkapi siklus S-adenosilmetionin (SAM). Dalam siklus ini, S-adenosilmetionin diubah menjadi $\mathrm{S}$-adenosilhomosistein yang menghasilkan metilasi makromolekul fungsional utama dalam tubuh seperti DNA, RNA, neurotransmitter, lipid, protein, dan asam amino (Banihani, 2017). Penambahan gugus metil dalam makromolekul fungsional tersebut dapat mengatur aktivitas sel sehingga sel mengalami pematangan dan dapat melindungi diri dari radikal bebas.

Manzanarez and Gil (2010) menya-takan bahwa mekanisme potensial dari pemberian vitamin B12 salah satunya adalah menstimulasi fosforilasi oksidatif. Fosforilasi oksidatif merupakan lintasan metabolisme untuk menghasilkan energi berupa ATP (Adenosine Tri Phosphate). Dalam mekanisme ini vitamin B12 bekerja dengan memberikan transport elektron dalam mitokondria sehingga terciptanya gradien konsentrasi proton $\left(\mathrm{H}^{+}\right)$yang digunakan untuk sintesis ATP dalam fosforilasi oksidatif, ATP ini dibutuhkan spermatozoa untuk motilitas menuju sel telur betina.

Kedua reaksi antioksidan ini membe-rikan efek positif perlindungan ganda yang diberikan dari mekanisme kerja kedua vitamin ini dalam menangkal radikal bebas dan dalam pembentukan energi untuk motilitas menghasilkan persentase motilitas yang lebih tinggi. Hal ini dibuktikan dalam perlakuan P2 terjadi perbedaan yang nyata $(\mathrm{p}<0,05)$ dibandingkan dengan $\mathrm{P} 0$ atau kontrol dan menunjukkan hasil Post Thawing Motility (PTM) lebih tinggi diantara P1 dan P0 atau kontrol.

Kecepatan gerakan individu spermato-zoa domba Sapudi post thawing pada perlakuan P0, P1 dan P2 tidak menunjukkan perbedaan yang nyata $(p>0,05)$. Hasil pemeriksaan dari ketiga perlakuan tersebut menunjukkan rerata angka 3 . Hasil ini menunjukkan bahwa motilitas spermatozoa domba Sapudi post thawing berada di atas standar gerakan individu spermatozoa minimal skor 2 (Ditjennak, 2016).

\section{Pemeriksaan Viabilitas Spermato- zoa Post Thawing}

Hasil pemeriksaan persentase viabilitas spermatozoa domba Sapudi post-thawing setelah diberi perlakuan dapat dilihat dalam tabel 4.

Reaksi berantai dari peroksidasi lipid dapat diputus dengan antioksidan vitamin $\mathrm{C}$ (asam askorbat). Asam askorbat merubah bentuk strukturnya menjadi radikal askorbat dengan memberikan satu elektronnya ke radikal peroksil untuk mengakhiri reaksi berantai peroksidasi lipid (Nimse and Dilipkumar, 2015).Reaksi penangkapan radikal peroksidasi lipid oleh 
antioksidan: $\mathrm{ROO}^{\circ}+\mathrm{AH} \rightarrow \mathrm{ROOH}+$ $\mathrm{A}^{\circ}$. Reaksi ter-sebut menghasilkan radikal askorbat $\left(\mathrm{A}^{\circ}\right)$ namun tidak memiliki cukup energi untuk menimbulkan reaksi radikal berbahaya. Ra-dikal askorbat ini dapat direduksi kembali menjadi asam askorbat atau dioksidasi men-jadi asam dehidroaskorbat (Nimse and Di-lipkumar, 2015).

Vitamin B12 bekerja dengan memberi perlindungan terhadap peroksidasi lipid spontan dengan meningkatkan aktivitas peroksidase glutation. Aktivitas peroksidase glutation dapat mengubah radikal $\mathrm{OH}^{-}$ (Hidroksil) menjadi $\mathrm{H}_{2} \mathrm{O}$ (molekul air). Vitamin B12 dalam pengencer sperma bekerja dengan menurunkan jumlah ROS berlebih yang dihasilkan dari proses oksidasi metabolisme spermatozoa selama proses pembekuan terjadi (Manzanares and Gil, 2010).

Molekul nonpolar seperti oksigen merupakan hidrofobik atau zat yang tidak dapat larut dalam air tetapi larut dalam lemak sehingga oksigen dapat dengan mudah melewati membran. Kelebihan jumlah oksigen dalam membran spermatozoa menyebabkan terbentuknya rantai radikal bebas. Vitamin $\mathrm{C}$ yang ditambahkan dalam pengencer bekerja dengan memasuki struktur lipid membran dengan memutus rantai radikal yang terjadi dan mengakhiri reaksi berantai peroksidasi lipid. Peroksidase glutation merupakan enzim intraseluler yang aktivitasnya ditemukan di mitokondria sel. Vitamin B12 merupakan koenzim dalam reaksi peroksidase glutation. Reaksi ini menghasilkan molekul air $\left(\mathrm{H}_{2} \mathrm{O}\right)$ dengan mengubah radikal $\mathrm{OH}^{-}$atau hidroksil. Peningkatan aktivitas reaksi enzim ini dapat melindungi membran mitokondria dari kerusakan akibat radikal bebas, membran mitokondria yang terlindungi akan menghasilkan ATP sebagai energi dari spermatozoa untuk bertahan hidup dan bergerak. Kombinasi kedua vitamin ini memberikan perlindungan yang optimal terhadap kerusakan membran plasma spermatozoa akibat terjadinya peroksidasi lipid.

Kerusakan membran plasma juga dipengaruhi oleh metode thawing yang digunakan. Penelitian ini menggunakan metode thawing semen beku domba dengan suhu $\pm 37^{\circ} \mathrm{C}$ selama 15 detik. Semakin cepat perubahan suhu thawing dapat mengurangi tekanan spermatozoa melewati masa tidak stabil (kritis) dengan cepat, sehingga spermatozoa hidup dan normal lebih banyak (Sari, 2008). Thawing dengan suhu $37^{\circ} \mathrm{C}$ dapat membantu semen untuk melewati masa kritisnya dengan cepat karena suhu tersebut sama dengan temperatur tubuh ternak (Utomo dan Boquifai, 2010). Proses metabolisme yang meningkat pada suhu $37^{\circ} \mathrm{C}$ tidak akan mengurangi substrat energi spermatozoa sehingga motilitas spermatozoa akan tinggi karena tidak kekurangan energi (Zenichiro et al., 2002). Lama pencelupan pada air thawing yang pendek memberikan sedikit kerusakan sehingga spermatozoa hidup lebih maksimal dan tetap memiliki kemampuan membuahi ovum yang tinggi (Sari, 2008).

Tabel 3. Post ThawingMotility Spermatozoa Domba Sapudi

\begin{tabular}{cccc}
\hline Perlakuan & Ulangan $(\mathrm{n})$ & $\begin{array}{c}\text { Post Thawing Motility (PTM) } \\
\text { Spermatozoa }(\%) \\
\text { (rerata } \pm \text { standar deviasi) }\end{array}$ & $\begin{array}{c}\text { Kecepatan Gerak } \\
\text { Spermatozoa }\end{array}$ \\
\hline P0 & 6 & $41,67^{\mathrm{a}} \pm 5,164$ & 3 \\
P1 & 6 & $40,83^{\mathrm{a}} \pm 2,041$ & 3 \\
P2 & 6 & $55,00^{\mathrm{b}} \pm 4,472$ & 3 \\
\hline
\end{tabular}

Keterangan:Superskrip yang berbeda pada kolom yang sama menunjukkan perbedaan yang nyata $(\mathrm{p}<0,05)$

Tabel 4. Viabilitas Spermatozoa Domba Sapudi Post Thawing

\begin{tabular}{ccc}
\hline Perlakuan & Ulangan (n) & $\begin{array}{c}\text { Viabilitas Spermatozoa (\%) } \\
\text { (rerata } \pm \text { standar deviasi) }\end{array}$ \\
\hline P0 & 6 & $56,50^{\mathrm{a}} \pm 4,930$ \\
P1 & 6 & $54,17^{\mathrm{a}} \pm 2,927$ \\
P2 & 6 & $69,33^{\mathrm{b}} \pm 3,077$ \\
\hline
\end{tabular}

Keterangan:Superskrip yang berbeda pada kolom yang sama menunjukkan perbedaan yang nyata $(\mathrm{p}<0,05)$ 


\section{Kesimpulan}

Berdasarkan penelitian yang telah dilakukan dapat disimpulkan bahwa penggantian dan penambahan vitamin B12 sebanyak $5 \mu \mathrm{g} / \mathrm{ml}$ dalam pengencer susu skim kuning telur mampu mempertahankan persentase motilitas dan viabilitas spermatozoa domba Sapudi post thawing.

\section{Daftar Pustaka}

Asadpour, R., M.M. Pourseif., G. Moghadam., R.Jafari., H. Tayei and H. Mahmodi. 2012. Effect of Vitamin B12 addition to Extenders on Some Physochemical Parameters of Semen in Crossbred Rams. African Journal of Biotechnology. 11(54): 11741-11745.

Banihani, S. A. 2017. Vitamin B12 and Semen Quality. Jordan University of Science and Technology. Jordan. 4-5.

Direktorat Jenderal Peternakan. 2016. Pedoman Teknis Penyediaan Semen Beku, Tenaga Teknis dan Sarana IB serta Pelaksaan IB. Departemen Pertanian Direktorat Jenderal Peternakan dan Kesehatan Hewan. Jakarta.

Dinas Peternakan Daerah Propinsi Jawa Timur. 2017. Data Statistik Populasi Ternak Propinsi Jawa Timur. /http.www.disnak.jatimprov.go.id/web /data/datastatistik/statistikpopulasitern ak. [28 November 2017].

Gazali, Muhamad dan S.N. Tambing. 2002. Kriopreservasi Sel Spermatozoa. Hayati. 9(1) : 27-32.

Hardijanto., S. Susilowati., T. Hernawati., T. Sardjito., dan T.W. Suprayogi. 2010. Inseminasi Buatan. Fakultas Kedokteran Hewan. Univeritas Airlangga. Airlangga University Press. Surabaya. 75-91.

Herdis., I. Kusuma., M. Surachman., M. Rizal., I. K. Sutama., I.Indunu., B. Purwantara dan I. Arifiantini. 2002. Peningkatan Kualitas Semen Beku Domba Garut melalui Penambahan $\alpha$ Tokoferol ke dalam Pengencer SusuSkim Kuning Telur. JITV. 7(1):12-17.

Inounu, I. 2014. Upaya Meningkatkan Keberhasilan Inseminasi Buatan pada Ternak Ruminansia Kecil. Wartazoa. Bogor. 24(4):201-209.

Kusriningrum. 2008. Perancangan Percobaan. Airlangga University Press. Surabaya. 44 .
Manzanares, William dan Gil Hardy. 2010. Vitamin B12 : The Forgotten Micronutrient for Critical Care. Wolters Kluwer Health. 13: $662-668$.

Muino-Blanco, T., R. Perez-Pe dan J.A. Cebrian-Perez. 2008. Seminal Plasma Proteins and Sperm Resistance to Stress. Reprod Dom Anim. 43(4):1831.

Nimse, S.B dan Dilipkumar Pal. 2015. Free Radicals, Natural Antioxidants, and Their Reaction Mechanisms. The Royal Society of Chemistry. 5:2798628006

Pamungkas, F.A. 2009. Potensi dan Kualitas Semen Kambing dalam Rangka Aplikasi Teknologi Inseminasi Buatan. Wartazoa. 19(1):17-22

Rizal, M. dan Herdis. 2010. Peranan Antioksidan Dalam Meningkatkan Kualitas Semen Beku. Makalah Ilmiah. Jakarta. 112-118

Sari, S.N. 2008. Pengaruh Suhu dan Lama Thawing terhadap Kualitas Spermatozoa Sapi Fries Holland. [Skripsi]. Fakultas Sains dan Teknologi. Universitas Islam Negeri Malang. Malang.

Setyaningsih, N.I. 2012. Pengaruh Penambahan Vitamin $\mathrm{C}$ dalam Pengencer Tris Kuning Telur Terhadap Motilitas dan Viabilitas Spermatozoa Domba Merino Post Thawing. [Skripsi].Fakultas Kedokteran Hewan. Univer-sitas Airlangga. Surabaya.

Susilowati, S., Hardijanto., T.W. Suprayogi., T. Sardjito dan T. Hernawati. 2010. Penuntun Praktikum Fisiologi dan Teknologi Reproduksi (IB). Fakultas Kedokteran Hewan. Universitas Airlangga. Surabaya. 11-22, 35-36.

Tiesnamurti, B., dan A. A. Santiananda. 2006. Pengelolaan dan Pemanfa-atan Sumber Daya Genetik Domba Sapudi. Prosiding Lokakarya Nasional Pengelolaan dan Perlindungan Sumber Daya Genetik di Indonesia.

Utomo, S dan E. Boquifai. 2010. Pengaruh Temperatur dan Lama Thawing terhadap Kualitas Spermatozoa Sapi dalam Penyimpanan Straw Beku. Sains Peternakan. Yogyakarta. 8(1):22-25.

Zenichiro dkk., 2002. Intruksi Praktis Teknologi Prosesing Semen Beku pada Sapi. Balai Besar Inseminasi Buatan Singosari-JICA. Malang. 